\title{
TINJAUAN YURIDIS MENGENAI KEABSAHAN PERKAWINAN PARIBAN DALAM HUKUM ADAT BATAK TOBA DIHUBUNGKAN DENGAN UNDANG- UNDANG NOMOR 1 TAHUN 1974 TENTANG PERKAWINAN
}

\author{
Oleh : \\ Rena Megawati \\ Mahasiswi Magister Ilmu Hukum Program Pascasarjana Universitas Katolik Parahyangan. \\ megawati.rena@gmail.com
}

\begin{abstract}
ABSTRAK
Perkawinan pariban merupakan perjodohan dimana pengantin pria adalah anak kandung dari pihak ibu dan pengantin wanita adalah anak kandung dari pihak ayah. Pendekatan normatif yuridis dengan deskriptif analitis merupakan metode penelitian yang digunakan dalam tulisan ini. Perkawinan pariban dalam adat Batak Toba adalah sah dan dapat dilakukan, karena sah menurut Pasal 2 Ayat (1) dan Ayat (2) UndangUndang Nomor 1 Tahun 1974 tentang Perkawinan Lembaran Negara Republik Indonesia Tahun 1974 Nomor 1.
\end{abstract}

Kata kunci: perkawaninan pariban, hukum adat batak

\section{ABSTRACT}

Pariban marriage is an arranged marriage in which the groom is the biological child of the mother and the bride is the biological child of the father. Normative juridical approach to the descriptive analysis is a method of research used in this paper. Marriage pariban in Batak Toba is valid and can be done, because legal under Article 2 Paragraph (1) and Paragraph (2) of Law No. 1 of 1974 on Marriage.

Keywords: pariban marriage, indegeous bataknese law.

\section{A. Pendahuluan}

Indonesia merupakan suatu Negara Kesatuan yang terdiri dari berbagai Suku Bangsa dan Budaya. Sebagian Suku Bangsa Indonesia yang mendiami pulau di Indonesia terdapat di Pulau Sumatera sebelah Utara antara lain Suku Batak Toba dan Suku Batak Karo. Sistem Hukum Adat merupakan sistem hukum yang pertama kali berlaku dan sebagai pencerminan kesadaran hukum dari Bangsa Indonesia, meskipun bentuknya tidak tertulis namun tetap diakui dan ditaati oleh masyarakat.. ${ }^{1}$

Secara umum Suku bangsa Batak mempunyai 6 (enam) rumpun yaitu: Batak Toba, berdiam di sekitar danau Toba; Batak Mandailing, berdiam di sekitar Tapanuli Selatan; Angkola, mendiami Angkola dan Sipirok; Batak Karo, berdiam di Tanah Karo;Batak Simalungun, berdiam di Simalungun;dan Pakpak, berdiam di Dairi/Pakpak. $^{2}$

Suku Batak sebagai salah satu etnis yang telah lama mendiami wilayah Indonesia, memiliki sistem kepercayaan yang dinamakan Sistem Kepercayaan Adat Batak. Sistem ini terkait dengan sistem garis keturunan ayah atau yang lebih dikenal dengan patrilineal, ${ }^{3}$ yang memberikan tempat bagi seorang anak laki-laki lebih utama dibandingkan anak

\footnotetext{
${ }^{1}$ R. Otje Salman, Kesadaran Hukum Masyarakat Terhadap Hukum Waris, Alumni, Bandung, 1993, hlm. 7.

${ }^{2}$ Payung Bangun, "Kebudayaan Batak dalam Manusia dan Kebudayaan di Indonesia, Koentjaraningrat, editor, Djambatan, Jakarta, 1982, hlm. 94-95

${ }^{3}$ Patrilineal mengikuti keturunan sebelum bapak atau orang tua lelakinya, oleh karena itu hanya laki laki saja yang menyambung marga bapaknya dan bukan marga dari pihak ibunya, maka nama-nama marga atau clan nama-nama suku mandailing, baik pria dan wanita suku mandailing memakai marga berasal dari nama marga bapaknya (orang tua laki). Bagi wanita suku Mandailing yang bermarga tetap memakai marga bapaknya (orangtua laki) dan tidak memakai marga suaminya setelah menikah. Lihat Pandapotan Nasution, Adat Budaya Mandailing Dalam Tantangan Zaman, Forkala Prov. Sumatera Utara, 2005.
}

TINJAUAN YURIDIS MENGENAI KEABSAHAN PERKAWINAN PARIBAN DALAM HUKUM ADAT BATAK TOBA DIHUBUNGKAN DENGAN UNDANG-UNDANG NOMOR 1 TAHUN 1974 TENTANG PERKAWINAN 
perempuan dalam sebuah keluarga. serta sudah merupakan budaya yang mendarah daging bagi orang batak. Lahirnya anak laki-laki dalam kehidupan Adat Batak memiliki peran penting dalam suatu keluarga, sehingga seorang wanita yang dilahirkan dalam suatu keluarga selalu mendambakan agar dia mempunyai iboto (anak laki-laki) agar kebahagiaannya tidak pincang. ${ }^{4}$

Sofia Rangkuti Hasibuan mengungkapkan bahwa Hukum Adat Batak mengatur seluruh peristiwa kehidupan dalam masyarakat antara lain, peristiwa kelahiran, perkawinan, dan kematian yang memperoleh porsi pengaturan istimewa dalam Adat Batak. Perkawinan sebagai salah satu bagian dari adat batak yang berhubungan dengan peristiwa kehidupan Sistem Kepercayaan Adat Batak, menjadi suatu peristiwa yang diatur secara tegas dalam Adat Batak. Perkawinan pada orang batak pada umumnya, merupakan suatu pranata yang tidak hanya mengikat seorang laki-laki dengan seorang perempuan, tetapi juga mengikat dalam suatu hubungan yang tertentu. ${ }^{5}$

Hukum Perkawinan Adat Batak mengenal suatu perkawinan adat yang disebut dengan "Pariban", yaitu di mana mempelai laki-laki dan mempelai perempuan mempunyai hubungan keluarga sebagai saudara sepupu kandung yang berbeda marga. Masyarakat yang telah mengenal istilah "Pariban" yang dipakai oleh orang batak, banyak dibicarakan karena berhubungan dengan adat, silsilah, dan juga kepribadian dari orang batak. Banyak orang menganggap fenomena "Pariban" sebagai sebuah istilah kuno-nya orang batak yang secara langsung tidak lagi dapat dipraktekan untuk saat ini. ${ }^{6}$

Perkawinan Suku Batak dikenal perkawinan yang tidak boleh dilaksanakan atau incest (semarga). Perkawinan Incest dalam Adat Batak bisa terjadi apabila pernikahan dilakukan oleh dua orang dengan marga yang sama (semarga), perkawinan dilakukan apabila seorang laki-laki memiliki marga yang sama dengan ibu dari seorang perempuan (martulang) dan perkawinan dilakukan oleh dua orang yang berbeda marga, namun diantara leluhur kedua marga tersebut berkerabat dari sumpah leluhur (marsipadan). ${ }^{7}$

Pemaknaan perkawinan sedarah dilarang atau tidak diperbolehkan di Indonesia tidak hanya menjadi wilayah aturan hukum yang berlaku dalam Sistem Kepercayaan Adat Batak, melainkan pula secara jelas dan tegas dilarang juga. Sebagaimana diungkapkan dalam Pasal 8 huruf b Undang-Undang Nomor 1 Tahun 1974 tentang Perkawinan bahwa :

Perkawinan dilarang antara dua orang yang:

"Berhubungan darah dalam garis keturunan menyamping yaitu antara saudara, antara seorang dengan saudara orang tua dan antara seorang dengan saudara neneknya".

Undang-Undang ini mengatur mengenai perkawinan dan segala sesuatu yang berhubungan dengan perkawinan. Pasal 1 Undang-Undang Perkawinan menerangkan bahwa:

"Perkawinan adalah ikatan lahir batin antara seorang pria dengan seorang wanita sebagai suami istri dengan tujuan membentuk keluarga (rumah tangga) yang bahagia dan kekal berdasarkan Ketuhanan Yang Maha Esa".

\footnotetext{
${ }^{4}$ Aji Nagara Pardede, "Tata cara pelaksanaan adat Batak", http://www.google.com Jumat, 12 Maret 2010.

${ }^{5}$ Sofia Rangkuti Hasibuan, Manusia dan Kebudayaan di Indonesia, Dian Rakyat, Jakarta, 2007. hlm. 102.

${ }^{6}$ Lihat Edward Bruner, Kerabat dan Bukan Kerabat dalam Pokok-pokok Antropologi Budaya, Jakarta: Gramedia, 1986, hlm. 164. Beberapa diantaranya telah mengetahui, bahwa pariban merupakan warisan perjodohan kuno orang batak yang unik dan terkadang tampak tidak rasional lagi untuk saat ini. Pariban biasanya sering dianjurkan untuk dijadikan keluarga atau untuk dikawini

${ }^{7}$ Catharina Dewi Wulansari, Hukum Adat Indonesia Suatu Pengantar, Refika Aditama, Bandung, 2010. hlm. 64. Perkawinan antara laki-laki dengan perempuan dalam satu marga tidak diijinkan karena dianggap sebagai saudara kandung. Selain Perkawinan Incest (semarga), terdapat juga larangan perkawinan karena ikatan hubungan kekerabatan yang dapat terlihat dalam Hukum Adat Batak yang bersifat asymmetrischt connubium, dilarang terjadinya perkawinan antara laki-laki dengan perempuan yang satu marga
} 
Pasal 1 Undang-Undang Perkawinan tersebut mengandung pengertian dan tujuan perkawinan. Pengertian Perkawinan adalah ikatan lahir batin antara seorang pria dengan seorang wanita. Sedangkan tujuan perkawinan adalah membentuk suatu keluarga (rumah tangga) yang bahagia, kekal berdasarkan Ketuhanan Yang Maha Esa.

Perkawinan Berbahagialah Bangsa Indonesia yang telah memiliki Undang-undang Perkawinan yang bersifat Nasional, yang sifatnya telah dinyatakan menampung sendisendi dan memberikan landasan Hukum Perkawinan yang selama ini telah menjadi pedoman dan pegangan serta berlaku bagi berbagai golongan masyarakat Indonesia, namun suatu kenyataan yang tidak dapat dipungkiri di sebagian besar kalangan masyarakat adat masih berlaku adat dan tata upacara perkawinan yang berbeda-beda. Undang-undang No. 1 Tahun 1974 merupakan unifikasi Hukum Perkawinan yang secara aturan umum berlaku untuk perkawinan di Indonesia. Hal ini dapat dilihat pada Pasal 2 ayat (1 dan 2). ${ }^{8}$

Penelitian ini merupakan penelitian deskriptif analitis, yaitu penelitian yang menggambarkan dan menganalisis secara sistematis, faktual, dan akurat tentang peraturan perundang-undangan yang terkait dengan keabsahan perkawinan pariban yang meletakkan dasar Sistem Kepercayaan Adat Batak sebagai acuan dalam terhadap pengesahan perkawinan Suku Batak.

Metode pendekatan yang digunakan dalam penelitian ini adalah metode pendekatan yuridis normatif. Penelitian hukum normatif merupakan penelitian kepustakaan, yaitu penelitian terhadap data sekunder atau data kepustakaan. Penelitian ini mengkaji data sekunder mengenai perkawinan pariban dalam ruang lingkup aturan perkawinan di Indonesia yang merujuk kerpada Undang-Undang Nomor 1 Tahun 1974 tentang Perkawinan.

\section{B. Pembahasan}

Masyarakat Batak Toba menganut sistem perkawinan eksogami, yaitu seorang batak itu hanya boleh kawin dengan orang diluar marganya ${ }^{9}$. Sistem perkawinan ini tidak boleh dilanggar, jika seorang batak melanggar dan melakukan perkawinan dengan yang semarga dengannya, maka orang yang melakukan perkawinan tersebut akan dihukum oleh pemuka-pemuka adat.

Bentuk perkawinan yang terdapat pada masyarakat Batak Toba adalah bentuk perkawinan jujur, karena keluarga pihak laki-laki menyerahkan jujur kepada pihak keluarga perempuan. Di dalam bahasa Batak Toba jujur itu disebut sinamot, biasanya sinamot berupa uang tetapi ada juga berupa barang yang besar atau jumlahnya sesuai dengan kesepakatan para pihak ${ }^{10}$.

Pariban sebenarnya menjodohkan seorang anak laki-laki dan perempuan pada waktu di dalam kandungan tetapi sekarang kebanyakan orang batak sudah tidak menjodohkan anak seperti itu, melainkan ketika anak mereka sudah dewasa, para orang tua batak menjodohkan anak mereka pada keluarga mereka sendiri. Sebenarnya maksud orang batak menjodohkan anak mereka hanya untuk menjaga keutuhan harta keturunan mereka, agar harta yang mereka miliki jatuh kepada saudaranya sendiri bukan pada orang lain.

Contoh pariban : seperti si A mempunyai anak $\mathrm{C}$ dan kakak kandung perempuan si B punya anak si D.mereka sudah mempunyai anak masing-masing. Ketika anak mereka besar dan tumbuh menjadi seorang anak yang dewasa, kedua kakak beradik si A dan si B ini menjodohkan anaknya si $\mathrm{C}$ dan $\mathrm{D}$ itu, akan tetapi sebenarnya budaya pariban itu dulu menjodohkannya ketika si C atau si D di dalam kandungan dan salah satu orang tua

\footnotetext{
${ }^{8}$ I Gede A. B. Wiranata, Hukum Adat Indonesia, PT. Citra Aditya Bakti, Bandung, 2005, hlm. 274.

${ }^{9}$, hlm. 3.

${ }^{10}$ Soerojo Wignjodipoero, Pengantar dan Asas-Asas Hukum Adat, Penerbit Toko Gunung Agung, Jakarta, 1995, hlm. 128.

TINJAUAN YURIDIS MENGENAI KEABSAHAN PERKAWINAN PARIBAN DALAM HUKUM ADAT BATAK TOBA DIHUBUNGKAN DENGAN UNDANG-UNDANG NOMOR 1 TAHUN 1974 TENTANG PERKAWINAN 
berkata bahwa "ketika anak itu lahir,dia akan ku jadian menantu" ini lah yang di sebut Pariban pada kebudayaan batak dulu. Tetapi pada zaman ini orang batak menjodohkan anaknya ketika anak itu sendiri sudah dewasa.

Pada umumnya tradisi Pariban ini sudah banyak ditinggalkan pada orang batak yang hanya mengetahui batak hanya sepintas, tetapi orang batak asli masih melestarikan tradisi atau adat istiadat mereka dari nenek moyang agar anak cucuknya mengetahui sejarah kebudayaan daerahnya ataupun adat istiadat yang selama ini diterapkan oleh nenek moyangnya dulu. Namun, sistem perkawinan semacam itu sudah tidak begitu diminati lagi. Perkawinan yang lebih bebas dengan marga lain yang tidak ada hubungan darah bahkan dengan etnis lain justru lebih digemari.

Pada hakikatnya suatu perkawinan mengandung unsur yang berkaitan dengan dapat atau tidaknya seseorang mempertanggungjawabkan perbuatan hukum yang dilakukannya, selain itu suatu perkawinan harus memenuhi persyaratan usia di mana kedua calon mempelai yang akan melangsungkan perkawinan telah memenuhi persyaratan usia supaya perkawinan tersebut dapat dilaksanakan berdasarkan Undang-Undang Nomor 1 Tahun 1974 Tentang Perkawinan yang menggambarkan kecakapan seseorang untuk bertindak dalam lalu lintas hukum, khususnya dalam bidang hukum perdata ${ }^{11}$.

Tujuan perkawinan membawa konsekuensi logis sebagaimana disebutkan dalam penjelasan umum Undang-undang Perkawinan adalah sebagai berikut: ${ }^{12}$

a. Perkawinan bertujuan untuk membentuk keluarga yang terdiri dari ayah, ibu, dan anak serta kehadiran anak itu menimbulkan hubungan-hubungan hukum dengan ayah maupun ibu.

b. Tujuan perkawinan adalah membentuk keluarga yang bahagia dan kekal. Untuk itu suami istri perlu saling membantu dan melengkapi agar masing-masing dapat mengembangkan kepribadiannya membantu dan mencapai kesejahteraan spiritual dan materiil.

c. Undang-undang ini menganut prinsip mempersukar terjadinya perceraian, dikarenakan tujuan perkawinan adalah untuk membentuk keluarga yang bahagia, kekal, dan sejahtera harus ada alasan tertentu serta harus dilakukan di depan sidang pengadilan.

Selanjutnya apabila dihubungkan dengan asas-asas perkawinan yang dianut oleh Undang-undang No. 1 Tahun 1974, maka asas-asas perkawinan menurut hukum adat adalah sebagai berikut: ${ }^{13}$

a. Perkawinan bertujuan membentuk keluarga rumah tangga dan hubungan kekerabatan yang rukun dan damai, bahagia dan kekal.

b. Perkawinan tidak saja harus sah dilaksanakan menurut hukum agama dan atau kepercayaan, tetapi juga harus mendapat pengakuan dari para anggota kerabat.

c. Perkawinan dapat dilakukan oleh seorang pria dengan beberapa wanita sebagai istri yang kedudukannya masing-masing ditentukan menurut hukum adat setempat.

d. Perkawinan harus didasarkan atas persetujuan orang tua dan anggota kerabat. Masyarakat adat dapat menolak kedudukan suami atau istri yang tidak diakui masyarakat adat.

e. Perkawinan dapat dilakukan oleh pria dan wanita yang belum cukup umur atau masih anak-anak. Begitu pula walaupun sudah cukup umur perkawinan harus berdasarkan izin orang tua atau keluarga dan kerabat.

\footnotetext{
${ }^{11}$ Wahyono Darmabrata, Tinjauan Undang-Undang Nomor 1 Tahun 1974 Tentang Perkawinan Beserta Peraturan Pelaksanaannya, Gitama Jaya Jakarta, Jakarta, 2003, hlm. 19.

${ }^{12}$ Undang-Undang Nomor 1 Tahun 1974 tentang Perkawinan Bagian Penjelasan Umum.

${ }^{13}$ Hilman Hadikusuma, Hukum Perkawinan Adat, Alumni, Bandung, 1977, hlm. 71.
} 
f. Perceraian ada yang dibolehkan dan ada yang tidak dibolehkan. Perceraian antara suami dan istri dapat berakibat pecahnya hubungan kekerabatan antara dua pihak.

g. Keseimbangan kedudukan antara suami dan istri-istri berdasarkan ketentuan hukum adat yang berlaku, ada istri yang berkedudukan sebagai ibu rumah tangga dan ada istri yang bukan ibu rumah tangga.

Segala sesuatu yang dapat menjadi sebab perkawinan tidak dapat dilakukan, atau jika dilakukan maka keseimbangan masyarakat menjadi terganggu, kita sebut "larangan perkawinan". Ada larangan perkawinan karena memenuhi persyaratan larangan agama yang telah masuk menjadi hukum adat, ada halangan perkawinan karena memenuhi ketentuan hukum adat, tetapi tidak bertentangan dengan hukum agama atau perundangundangan ${ }^{14}$.

Pasal 2 Undang-undang Perkawinan mengatur tentang sahnya perkawinan, yaitu: ${ }^{15}$

a. Perkawinan adalah sah apabila dilakukan secara hukum masing-masing agama dan kepercayaannya itu.

b. Tiap-tiap perkawinan dicatat menurut peraturan perundang-undangan yang berlaku. Sehubungan dengan ketentuan Pasal 2 Ayat (1) dan Ayat (2) di atas, kata sah berarti menurut hukum yang berlaku, kalau perkawinan itu dilaksanakan tidak menurut tata tertib hukum yang telah ditentukan maka perkawinan itu tidak sah. Jadi kalau tidak menurut aturan Undang-undang Perkawinan, berarti tidak sah menurut perundangan, kalau tidak menurut tata tertib hukum adat tidak sah menurut hukum adat.

Sahnya perkawinan menurut perundangan diatur dalam Pasal 2 Ayat (1) di atas, yang menyatakan bahwa "Perkawinan adalah sah, apabila dilakukan menurut hukum masing-masing agama dan kepercayaannya itu".

Jadi perkawinan yang sah menurut hukum perkawinan nasional adalah perkawinan yang dilaksanakan menurut tata tertib aturan hukum yang berlaku dalam agama Islam, Kristen/Katolik, Hindu/Budha. Kata "hukum masing-masing agamanya" berarti hukum dari salah satu agama itu masing-masing, bukan berarti "hukum agamanya masingmasing" yaitu hukum agama yang dianut oleh kedua mempelai atau keluarganya ${ }^{16}$.

Sebaliknya selain setelah dilaksanakan menurut hukum masing-masing agamanya, perkawinan juga harus dicatatkan sebagai bukti formal bahwa perkawinan memang telah dilangsungkan ${ }^{17}$.

Hukum adat adalah hukum yang tidak tertulis yang menjadi pedoman atau aturan yang mengatur kehidupan masyarakat. Hukum yang tidak tertulis mempunyai sifat dinamis dan berubah mengikuti perkembangan zaman. Dengan berlakunya Undang-Undang No. 1 Tahun 1974 Tentang Perkawinan Lembaran Negara Republik Indonesia Tahun 1974 Nomor 1, maka syarat-syarat sahnya perkawinan diatur oleh undang-undang tersebut kecuali bagi mereka yang tidak menganut suatu agama, maka syarat sahnya perkawinan ditentukan oleh hukum adat mereka yang memang sudah berlaku bagi mereka sebelum diundangkannya undang-undang perkawinan ini $^{18}$.

Sahnya perkawinan menurut hukum adat Batak Toba sesuai dengan ketentuan yang dinyatakan oleh Undang-Undang Nomor 1 Tahun 1974 Tentang Perkawinan Lembaran Negara Republik Indonesia Tahun 1974 Nomor 1, yaitu sahnya perkawinan berdasarkan agama masing-masing. Maka bagi masyarakat Batak Toba yang beragama, sahnya

\footnotetext{
${ }^{14}$ Hilman Hadikusuma, op.cit. hlm. 99-100.

${ }^{15}$ Undang-Undang Nomor 1 Tahun 1974 tentang Perkawinan.

16 Hilman Hadikusuma, Hukum Perkawinan Indonesia Menurut Perundangan Hukum Adat dan Hukum Agama, Penerbit Mandar Maju, Bandung, 2007, hlm. 25.

${ }^{17}$ Ibid, hlm. 72.

${ }^{18}$ Otje Salman, Op. Cit, hlm.175. 
perkawinan sesuai dengan apa yang ditentukan oleh hukum agamanya masing-masing mengenai syarat sah dan rukun perkawinan. Perkawinan menurut hukum adat adalah urusan kerabat, urusan keluarga, urusan masyarakat, urusan pribadi satu sama lain dalam hubungannya yang sangat berbeda-beda ${ }^{19}$. Jadi perkawinan menurut hukum adat adalah merupakan tanggung jawab bersama dari masyarakat hukum adat.

Suatu perkawinan yang sah, selain memenuhi ketentuan Pasal 2 Ayat (1) dan 2 Ayat (2), maka harus pula memenuhi syarat-syarat perkawinan, baik materil maupun formil, yang ditentukan oleh undang-undang. Syarat-syarat perkawinan yang dimaksud adalah terdiri dari:

1. Syarat Material

Syarat material adalah mengenai diri pribadi orang yang akan melangsungkan perkawinan. Dengan demikian syarat-syarat material ini langsung melekat pada diri calon mempelai.

Syarat material untuk dapat melangsungkan perkawinan bagi calon mempelai dapat dibagi ke dalam dua klasifikasi, yaitu sebagai berikut :

a. syarat material yang bersifat umum

Syarat material umum adalah persyaratan yang berlaku secara umum bagi semua perkawinan. Jadi syarat ini harus dipenuhi oleh semua calon mempelai, yaitu :

1) Asas Monogami

Asas ini diatur dalam Pasal 3 Ayat ( 1 ) Undang-Undang Nomor 1 Tahun 1974 Tentang Perkawinan Lembaran Negara Republik Indonesia Tahun 1974 Nomor 1, yang menegaskan bahwa : "dalam hal suami akan beristri lebih dari seorang, sebagaimana tersebut dalam Pasal 3 Ayat (2 ) undangundang ini, maka ia wajib mengajukan permohonan ke pengadilan di daerah tempat tinggalnya". Berarti pada dasarnya dalam waktu yang sama, maka seorang suami hanya dapat atau boleh beristri satu orang saja, sebaliknya seorang istri hanya boleh bersuami satu. Tetapi apabila para pihak menginginkan sesuai dengan ketentuan Pasal 3 Ayat ( 2 ), jo Pasal 4 Ayat ( 2 ) Undang-Undang No. 1 Tahun 1974 Tentang Perkawinan Lembaran Negara Republik Indonesia Tahun 1974 Nomor 1, dengan ketentuan :

a) istri tidak dapat menjalankan kewajibannya sebagai istri

b) istri mendapat cacat badan atau penyakit yang tidak dapat disembuhkan

c) istri tidak dapat melahirkan keturunan

2) Persetujuan antara kedua calon mempelai

3) Batas usia untuk melangsungkan perkawinan

Perkawinan hanya dijinkan jika pria sudah mencapai umur 19 tahun dan wanita mencapai usia 16 tahun. Persyaratan yang demikian sudah selayaknya diberikan, apabila usia kawin terlalu muda dikhawatirkan mereka belum cukup mampu untuk membentuk keluarga, yang kekal dan bahagia dan juga dikhawatirkan akan mudah menimbulkan penyakit.

4) Tenggang waktu (waktu tunggu) bagi seorang perempuan

Diatur dalam pasal 39 Peraturan Pemerintah Nomor 9 Tahun 1975.

b Syarat material yang bersifat khusus

Maksudnya adalah persyaratan yang hanya berlaku bagi perkawinan tertentu, artinya adalah dalam keadaan tertentu para pihak tidak dapat melangsungkan perkawinan (Pasal 8 jo Pasal 9 Undang-Undang Nomor 1 Tahun 1974 Tentang Perkawinan Lembaran Negara Republik Indonesia Tahun 1974 Nomor 1), yaitu :

19 Ter Haar Bzn, Asas-asas dan Susunan Hukum Adat, PT. Pradnya Paramita, Jakarta, 1999, hlm.159. 
1) Berhubungan darah dalam garis keturunan lurus ke atas atau ke bawah

2) Berhubungan darah dalam garis keturunan menyamping, yaitu antara saudara orang tua dan antara seseorang dengan saudara neneknya

3) Berhubungan semenda

4) Berhubungan susuan

5) Berhubungan saudara dengan istri atau sebagai bibi atau kemenakan dari istri dalam hal seorang suami yang beristri lebih dari seorang

6) Yang mempunyai hubungan yang oleh agamanya atau peraturan yang berlaku dilarang untuk kawin

7) Seseorang yang masih terikat perkawinan dengan orang lain tidak dapat kawin

8) Harus ada izin kawin ( Pasal 6 Ayat 1 hingga Ayat 5 Undang-Undang Nomor 1 Tahun 1974 Tentang Perkawinan Lembaran Negara Republik Indonesia Tahun 1974 Nomor 1.

Dengan demikian telah selesai dijabarkan tentang persyaratan material yang harus dipenuhi agar suatu perkawinan dapat berlaku secara sah.

2. Syarat Formal

Persyaratan ini adalah syarat yang menyangkut tentang formalitas tata cara yang mendahului dan menyertai kelangsungan perkawinan. Mengenai persyaratan formal untuk dapat dilangsungkan suatu perkawinan diatur dalam Peraturan Pemerintah Nomor 9 tahun 1975 yaitu sebagai berikut:

a. harus ada pemberitahuan kepada pegawai pencatatan perkawinan di tempat perkawinan itu dilangsungkan

b. adanya pengumuman oleh petugas pencatatan nikah tentang akan dilangsungkannya pernikahan. Perkawinan hanya dapat dilaksanakan setelah lewat 10 (sepuluh) hari pemberitahuan diumumkan

c. perkawinan harus dilangsungkan di muka umum, artinya dilangsungkan dihadapan pegawai pencatatan nikah dan bila ada pemberitahuan terlebih dahulu (Pasal 23 Undang-Undang Nomor 1 Tahun 1974 Tentang Perkawinan Lembaran Negara Republik Indonesia Tahun 1974 Nomor 1).

Penjelasan di atas untuk memahami dan menganalisis Keabsahan Perkawinan seseorang yang melaksanakan Perkawinan Pariban dalam Adat Batak Toba dihubungkan dengan Undang-undang Perkawinan No. 1 Tahun 1974.

Seperti yang telah dijelaskan sebelumnya, bahwa suatu keabsahan perkawinan sangat berkaitan erat dengan agama dan kepercayaan masing-masing di samping menurut peraturan lain lain yang berlaku. Selanjutnya apabila dihubungkan dengan Hukum Nasional lainnya, seperti asas-asas perkawinan yang dianut oleh Undang-undang No. 1 Tahun 1974, maka asas-asas perkawinan menurut hukum adat adalah sebagai berikut: ${ }^{20}$

a. Perkawinan bertujuan membentuk keluarga rumah tangga dan hubungan kekerabatan yang rukun dan damai, bahagia dan kekal.

b. Perkawinan tidak saja harus sah dilaksanakan menurut hukum agama dan atau kepercayaan, tetapi juga harus mendapat pengakuan dari para anggota kerabat.

c. Perkawinan dapat dilakukan oleh seorang pria dengan beberapa wanita sebagai istri yang kedudukannya masing-masing ditentukan menurut hukum adat setempat.

d. Perkawinan harus didasarkan atas persetujuan orang tua dan anggota kerabat. Masyarakat adat dapat menolak kedudukan suami atau istri yang tidak diakui masyarakat adat.

\footnotetext{
${ }^{20}$ Hilman Hadikusuma, op.cit, hlm. 71.
} 
e. Perkawinan dapat dilakukan oleh pria dan wanita yang belum cukup umur atau masih anak-anak. Begitu pula walaupun sudah cukup umur perkawinan harus berdasarkan izin orang tua atau keluarga dan kerabat.

f. Perceraian ada yang dibolehkan dan ada yang tidak dibolehkan. Perceraian antara suami dan istri dapat berakibat pecahnya hubungan kekerabatan antara dua pihak.

g. Keseimbangan kedudukan antara suami dan istri-istri berdasarkan ketentuan hukum adat yang berlaku, ada istri yang berkedudukan sebagai ibu rumah tangga dan ada istri yang bukan ibu rumah tangga.

Dengan melihat asas-asas perkawinan yang dianut oleh Undang-undang No. 1 Tahun 1974, maka dapat diartikan bahwa perkawinan yang dilakukan berdasarkan hukum adat masih dapat dilakukan, selama masih diperlukan dan tidak bertentangan dengan Hukum Nasional.

Jadi perkawinan yang sah menurut hukum perkawinan nasional adalah perkawinan yang dilaksanakan menurut tata tertib aturan hukum yang berlaku dalam agama Islam, Kristen/Katolik, Hindu/Budha. Kata "hukum masing-masing agamanya" berarti hukum dari salah satu agama itu masing-masing, bukan berarti "hukum agamanya masingmasing" yaitu hukum agama yang dianut oleh kedua mempelai atau keluarganya ${ }^{21}$.

Setelah menelaah secara lebih rinci, mengenai perkawinan yang dilaksanakan berdasarkan beberapa adat yang ada di Indonesia. Maka dapat disimpulkan bahwa pada dasarnya perkawinan pariban di dalam adat Batak Toba dapat dilaksanakan sebagaimana mestinya menurut adat Batak Toba sepanjang perkawinan adat tersebut berada di dalam koridor hukum seperti halnya sifat hukum adat yang bersifat dinamis dan tradisional. Di mana masih mengikuti leluhur nenek moyang, selama masih dibutuhkan dan tidak bertentangan dengan peraturan perundang-undangan yang berlaku karena adat yang menjadi bagian dan kepercayaan keagamaan harus mematuhinya.

Thomas Aquinas menguraikan bahwa dunia ini diatur oleh tatanan Ketuhanan, seluruh masyarakat dunia ini diatur oleh akal Ketuhanan. Hukum Ketuhanan adalah yang tertinggi $^{22}$. Hukum Adat dari segi sosiologis yaitu Hukum Adat sebagai suatu gejala sosial yang hidup dalam masyarakat Indonesia. Hukum Adat adalah hukum yang timbul dan terdapat dalam masyarakat Indonesia karena Hukum Adat adalah merupakan gejala sosial yang terdapat dalam masyarakat Indonesia, maka tentulah Hukum Adat itu mempunyai suatu sifat yang umum dan mempunyai jiwa yang tertentu.

Hukum Adat dari segi historis atau sudut sejarah berarti membicarakan riwayat tentang bagaimana para ahli-ahli menganalisa dan menyusun tentang Hukum Adat dari dahulu sampai sekarang. Beragamnya budaya berdampak pula pada perbedaan adat yang berlaku di daerah-daerah. Suku (baik Jawa, Batak, Sunda, Manado, Papua, dll) memiliki cara tersendiri dalam melihat perkawinan. Sahnya suatu perkawinan secara adat dapat di lihat dari apakah pasangan yang kawin telah melakukan semua prosesi perkawinan secara (1) Hukum Adat yang berlaku di komunitas suku tersebut; (2) petuah-petuah sesepuh adat; (3) kebiasaan-kebiasaan yang terjadi dalam komunitas tersebut. Seiring dengan perjalanan waktu, agama (Kristen, Islam, Budha, Hindu, dll) hadir dalam masyarakat suku-suku. Hal ini sudah tentu berdampak pada penerapan peraturan dalam agama-agama dalam proses perkawinan (Mesjid, Gereja, dll). ${ }^{23}$

Pembinaan hukum di sini disesuaikan dengan kesadaran hukum dalam masyarakat, dalam hal ini Hukum Adat menempati fungsi yang penting dalam kerangka dan proses pembentukan Hukum Nasional terutama diarahkan kepada Unifikasi Hukum. Hukum Adat

\footnotetext{
${ }^{21}$ Hilman Hadikusuma, Op. Cit, hlm. 25.

${ }^{22}$ Otje Salman, Teori Hukum, Refika Aditama, Bandung, 2005, hlm. 157.

${ }^{23}$ Fredy, "Pernikahan: Adat, Agama, Negara", webmaster@ @abdaspace.org, Sabtu, 13 Maret 2010. 
mempunyai sifat yang hidup dan berkembang, dinamis, bilamana hukum dapat mengikuti perkembangan masyarakat yang membutuhkan perubahan-perubahan dalam dasar-dasar hukum sepanjang jalan sejarahnya. ${ }^{24}$

Menurut para ahli antropologi, Suku Batak berasal dari perbatasan Birma dan Thailand (suku Karen) dan termasuk Proto-Melayu. Suku Batak menyebar dari daerah Toba ke daerah lain membentuk marga. Versi lain mengatakan, dari India melalui Barus atau dari Alas Gayo berkelana ke Selatan hingga bermukim di pinggir Danau Toba.

Menurut garis vertical, yaitu menentukan hubungan dan kedudukan seseorang menurut garis keturunan dengan menarik garis lurus ke atas maupun ke bawah. Suatu generasi tertentu yang lebih tinggi satu tingkat akan memanggil generasi yang di bawahnya dengan panggilan tertentu dan demikian sebaliknya generasi yang lebih rendah akan memanggil suatu panggilan tertentu kepada generasi yang lebih tua dari generasinya ${ }^{25}$.

Menurut garis horizontal, yaitu untuk menentukan hubungan dan kedudukan tingkat cabang dari seseorang menurut urut kelahiran dengan menarik garis keturunan dari pihak laki-laki (ayah). Oleh karena pada awalnya ada seorang yang disebut ayah asal maka ayah asal ini membawa sebutan marga tertentu. Ayah asal yang mempunyai marga tertentu ini mempunyai anak laki-laki lebih dari seorang dan anak laki-laki ini membawa sebutan marga sendiri-sendiri. Dalam menentukan anak marga mana yang lebih tua, maka akan ditentukan dari anak marga mana yang lahir lebih dulu ${ }^{26}$.

Sahnya perkawinan menurut hukum adat bagi masyarakat hukum adat di Indonesia pada umumnya bagi penganut agama tergantung pada agama yang dianut masyarakat adat bersangkutan. Maksudnya jika telah dilaksanakan menurut tata tertib hukum agamanya, maka perkawinan itu dianggap sah secara hukum adat. Kecuali bagi mereka yang belum menganut agama kepercayaan agama lama (kuno) maka perkawinan yang dilakukan menurut tata tertib adat/agama mereka itu adalah sah menurut hukum adat setempat. Hanya saja walaupun sudah sah menurut agama kepercayaan yang dianut masyarakat adat belum tentu sah menjadi warga adat dari masyarakat adat bersangkutan. Upacara meresmikan masuk menjadi warga adat ini merupakan upacara perkawinan adat.

\section{Penutup \\ Simpulan}

Perkawinan Pariban adalah perkawinan ideal di dalam kebudayaan adat Batak Toba, di mana perkawinan tersebut terjadi antara seorang pemuda dengan putri seorang laki-laki ibunya. Demikian juga bila seorang laki-laki kawin dengan putra saudara perempuan ayah yang dapat disebut juga sebagai kawin "Pariban". Perkawinan menurut hukum adat pada dasarnya mempunyai perbedaan peraturan dengan ketentuan Hukum Nasional. Perkawinan pariban menurut adat Batak Toba apabila dilakukan, maka perkawinan pariban tersebut adalah sah menurut hukum adat Batak Toba. Merujuk kepada Undang-Undang Nomor 1 Tahun 1974 tentang Perkawinan Lembaran Negara Republik Indonesia Tahun 1974 Nomor 1, di dalam Pasal 2 Ayat (1) dan Ayat (2) terdapat tentang ketentuan syarat sahnya seseorang yang akan melakukan suatu perkawinan, yaitu perkawinan adalah sah apabila dilakukan menurut hukum masing-masing agamanya dan kepercayaannya itu. Jadi masyarakat adat Batak Toba melakukan pernikahan pariban dapat dianggap sah apabila sesuai dengan agama dan kepercayaannya masing-masing serta perkawinan tersebut dicatat menurut peraturan perundang-undangan yang berlaku.

Pada umumnya tata cara pelaksanaan penerapan suatu peraturan perundangundangan, mengacu kepada ketentuan-ketentuan yang tercantum di dalam perundang-

\footnotetext{
${ }^{24}$ Otje Salman, Rekonseptualisasi Hukum Adat Kontemporer, Bandung, 2002, hlm. 35.

25 Ibid, hlm. 21

${ }^{26}$ Ibid, hlm. 22
} 
undangan maupun di dalam peraturan pelaksanaan dari undang-undang tersebut. UndangUndang Nomor 1 Tahun 1974 tentang Perkawinan Lembaran Negara Republik Indonesia Tahun 1974 Nomor 1 selain memuat Pasal 2 Ayat (1) dan Ayat (2) mengenai syarat sahnya perkawinan, terdapat juga Pasal 8 yang di dalamnya memuat mengenai larangan-larangan perkawinan. Merujuk pada isi dari Pasal 8 Undang-Undang Nomor 1 Tahun 1974 tentang Perkawinan Lembaran Negara Republik Indonesia Tahun1974 Nomor 1, maka perkawinan adat Batak Toba khususnya perkawinan pariban apabila dilakukan akan mengakibatkan perkawinan tersebut sah, karena mengacu kepada Pasal 2 Ayat (1) dan Ayat (2) UndangUndang Nomor 1 Tahun 1974 tentang Perkawinan Lembaran Negara Republik Indonesia Tahun 1974 Nomor 1 yang mengatur mengenai keabsahan perkawinan pariban di dalam adat Batak Toba.

\section{Daftar Pustaka}

\section{Buku}

Bzn, Haar, Ter, Asas-asas dan Susunan Hukum Adat, PT. Pradnya Paramita, Jakarta, 1999.

Darmabrata Haryono, Tinjauan Undang-Undang Nomor 1 Tahun 1974 Tentang Perkawinan Beserta Peraturan Pelaksanaannya, Gitama Jaya Jakarta, Jakarta, 2003.

Djaren Saragih, , Pengantar Hukum Adat, edisi II, Tarsito, Bandung, 1984.

Fredy, "Pernikahan: Adat, Agama, Negara”, webmaster@sabdaspace.org, Sabtu, 13 Maret 2010.

Hadikusuma, Hilman, Hukum Perkawinan Adat, Alumni, Bandung, 1977.

Hadikusuma, Hilman, Hukum Perkawinan Indonesia Menurut Perundangan Hukum Adat dan Hukum Agama, Penerbit Mandar Maju, Bandung, 2007.

Hasibuan, Rangkuti, Sofia, Manusia dan Kebudayaan di Indonesia, Dian Rakyat, Jakarta, 2007.

Pandapotan Nasution, Adat Budaya Mandailing Dalam Tantangan Zaman, Forkala Prov. Sumatera Utara, 2005.

Payung Bangun, "Kebudayaan Batak dalam Manusia dan Kebudayaan di Indonesia, Koentjaraningrat, editor, Djambatan, Jakarta, 1982.

Salman, Otje, Kesadaran Hukum Masyarakat Terhadap Hukum Waris, Alumni, Bandung, 1993.

Salman, Otje, Rekonseptualisasi Hukum Adat Kontemporer, Bandung, 2002.

Salman, Otje, Teori Hukum, Refika Aditama, Bandung, 2005.

Wignjodipoero, Soerojo, Pengantar dan Asas-Asas Hukum Adat, Penerbit Toko Gunung Agung, Jakarta, 1995.

Wulansari, Dewi, Catharina, Hukum Adat Indonesia Suatu Pengantar, Refika Aditama, Bandung, 2010.

Wiranata, I Gede A. B., Hukum Adat Indonesia, PT. Citra Aditya Bakti, Bandung, 2005. Internet

Aji Nagara Pardede, "Tata cara pelaksanaan adat Batak", http://www.google.com Jumat, 12 Maret 2010.

\section{Peraturan Perundang-Undangan}

Undang-Undang Nomor 1 Tahun 1974 tentang Perkawinan 